\title{
Article
}

\section{Border Militias}

\author{
Experience, Narrative, and the Moral Imperative to Act
}

\author{
John R Parsons \\ The University of Queensland
}

\begin{abstract}
Narratives of security and threat are continually used to justify morally contentious activities. In the past three years, the United States' government has increasingly promoted narratives of "criminal migrants" and "immigrant invasions." In response to perceived threats, the US-Mexico border has undergone a process of militarization. During this time, various border militias have continued to operate along the southern US border. My research was conducted over 11 months with two militias operating on the US-Mexico border I have labeled Border Watch. This militia provides a snippet of how morality is operationalized in the legitimization of actions and how morality is intrinsically linked to security in the lived experiences of its volunteers. In this article, I argue that the volunteers make sense of their experiences away from the border through the narrative espoused by the US government. The resonance between experience and narrative defines the latter as truth and the ability to dismiss counter-narratives. For the volunteers of Border Watch who adhere to a notion of citizenship through the lens of the citizen-soldier ideal, the narrative delivers a moral imperative to act in defense of the nation. Within the nexus of danger, security, and morality, the volunteers of Border Watch conceptualize their project as one in which moral citizens protect the nation and its citizens from an evil Other.
\end{abstract}

\section{Keywords}

morality, narrative, security, borders, militias

\section{Introduction}

The discourse linking immigration and security became a central topic in the leadup to the 2016 US presidential elections. The dialogue surrounding the security of the nation contained implicit moral and ethical obligations and concerns. Often used to legitimize, strike fear, and encourage mobilization, the dialogue continued a historical linkage between migrants and danger. In this article, I explore the lived experiences of a particular group of people that mobilized in response to security 
threats. Border Watch is the collective term I use to describe two US border militias and one militia that operated on the Mexico-US border. The existence of border militias predates the recent resurgence in political discourse that surrounds migration, as do the militias that form Border Watch. However, the narratives of migration and security in Border Watched evolved in parallel to those in the political discourse. In this article, I explore how the nexus of morality and the security of the nation are operationalized through narrative. I argue that the narratives of the border, often promoted by the news outlets and social media, situated Border Watch within a moral framework that called for individuals to act. It is a broader moral assemblage (Zigon 2010, 2009) that was founded upon a perceived relationship between the state and the individual: one in which it is the duty of the citizen to protect the nation when the state is perceived to be failing. I argue that the dominant narrative of the border within Border Watch held power not because it portrayed a desired world but because it made sense of the volunteers' profoundly emotional and often traumatic experiences away from the border. The emotional impact reified the narrative and provided the moral incentive for the volunteers to act. It was on the border, I argue, the volunteers believed they could make a difference.

I begin this article by introducing Border Watch. I then turn to the dominant narrative of the US-Mexico border I found in Border Watch, arguing that this narrative provided a means for the volunteers to make sense of their experiences away from the border. The narratives' ability to do so reified the truth of the narrative and the State's failure to protect its citizens. Which, through the lens of the citizen-soldier ideal many militias adhere to, provided the moral imperative for the volunteers to act.

\section{Border Militias}

Violence along the US - Mexico border has a very long history that followed its inception, formation, and the physical barriers that seek to define it. Border militias and loosely tied groups of concerned citizens have been patrolling the border for just as long. The numbers rise and fall with broader economic trends (Mize and Swords 2011) - from the posse that hung Rafael Benavides from a locust tree in 1928 (Carrigan and Webb 2003, Tórrez 2008), to the school children "beaner hunting" in San Diego in 1990 (Drury 1990). This century, the Minutemen Civil Defence Corp garnered national attention in 2005 as they congregated on the border in Arizona with deck chairs and RVs (Shapira 2013, Doty 2009). The 'spectacle in the desert' they created sought to spark radical immigration reform using the media influence to enforce change in the U.S. Congress (Chavez 2008, Doty 2009, Shapira 2013). In 2019, a border militia once again received international attention when a video surfaced on YouTube documenting the militia's "arrest" of over 200 migrants.

Today, the militias' activities are heavily politicized, leading many of them to avoid media, research, and internet exposure. As such, it is impossible to discern the ex- 
act number of groups as many remain known only through word of mouth. Border Watch is the amalgamation of two border militias with whom I conducted my research and one militia based in a border state. One border militia invited me to their operations on the border, the other to talk with their members and leaders each over an 11-month period between 2017-2018. In this time, I attended five operations on the US-Mexico border and one professional tactical tracking class with Border Watch. The militia's activities were legal. However, the volunteers were concerned about their representation and did not trust the media or my affiliation with a foreign university. My methods of data collection, by necessity, focused on participant observation and the informal conversations and experiences I had with the volunteers. To supplement participant observation, I conducted twelve interviews with volunteers of Border Watch. I conducted five around the camp on different occasions with my audio recorder. I conducted a further seven interviews as part of a documentary being made about one of the groups. Toward the end of my time with Border Watch, a small documentary crew accompanied several operations. The producer was a supporter of the organization, and the volunteers viewed him and his documentary positively. On my fourth operation, the documentary crew began a process of interviews, and the producer asked if I would conduct the interviews. Without a doubt, the formalized setting of the interviews with lights, cameras, and an audience altered the responses of the volunteers. Like my earlier interviews and those the volunteers gave to media outlets, performativity flowed throughout the interviews. The volunteers carefully considered their answers and avoided some topics entirely under guidance from the leadership. As a result, it is the informal interviews, conversations, and participant observation that form the bedrock of my work. The interviews I conducted provide valuable background and a point of comparison. In order to maintain the confidentiality of the border militias and volunteers' identities, the individuals within this article are composite characters.

The volunteers of Border Watch were a diverse group of people with different interests and concerns who came together only because of their concern over the Cartel. Despite politics being primarily absent from discussions during the operations, the volunteers were predominantly republican voters. All below retirement age worked in a variety of professions, though most fell within blue-collar categorizations. The volunteers ranged from their mid-20s to early 60 s and three in their 70 s. Only five women attended the operations I joined. One performed administerial duties around the camp, and work commitments dictated that she could only stay for several hours or one night at a time. Two women in their 70s joined the 'overwatch' team that surveyed the area from the tops of nearby mountains. A fourth I never met. In all operations I attended, only one woman joined a team for the "active" missions. Although most border militias claim to have upward of $90 \%$ ex-military members, within Border Watch, this figure averaged at 45\%. All volunteers were US-citizens hailing from across the country. A significant number were Native Americans, naturalized citizens from central and south America, and Europe. What each volunteer displayed, however, was a common concern for the 
US, a 'worrying' (Hage 2003) that united them and brought them to the US-Mexico border.

Border Watch conducted operations every two months in Arizona. Each operation consisted of two elements, reconnaissance missions, and multi-day missions. The first involved the search for "sign" across the area of operation. That is, looking for evidence that showed a particular trail had been used recently. For example, the integrity of water bottles signaled how long they had been in the sun. Food wrappers fade, and some perishable goods have short used by dates and provided a rough gage on time. Footprints offered the most exciting prospects as their existence was temporary. These missions occurred throughout an operation and built a continually changing picture of the surrounding location. Another aim of reconnaissance missions was to disrupt suspected scout positions on the mountains surrounding the valleys. The multi-day missions, in contrast, were carefully planned "traps" where the boredom, danger, and possible excitement happen. Based on the reconnaissance, specific trails were chosen to set up teams of between two-four volunteers. These teams were set up in ways that would surround and trap clandestine border crossers traveling on particular trails. Concerned for the watchful eyes of scouts, the volunteers used paths and trails that offered concealment for the teams to reach their designated positions. The volunteers packed their equipment, food, and toiletries for up to $48 \mathrm{hrs}$. In full camouflage, they traveled in silence to their designated locations. They maintained radio contact, but the radios were turned down low, and traffic kept to a minimum. Once in their locations, they bedded down for the duration of the mission. Eating, defecating, and sleeping in shifts in the same spot.

\section{The Narrative World of Border Watch}

Before an operation, I caught up with James and a couple of other volunteers at his house. James was of medium height, with short brown hair and a thick beard. The deep tan on his arms and face spoke of a life spent outside. He had worked in the construction industry in various parts of the US since leaving the military. At the time, he lived in a small town an hour from the US - Mexico border on a small property. James was one of the key leaders in Border Watch and spoke with the authority of experience about the border. Old carpet lined the floor of his small two-bedroom home. Several film posters were pinned to the wall of the office we sat in. Boxes were stacked in front of the single built-in cupboard, their contents unknown to me. On a desk by the window sat a sign one of the volunteers had made; burned black in wood were the words ' $E l$ Cucuy', the bogeyman. On the back wall, a large charger for the radios Border Watch carried was busy blinking. James was in the process of recalibrating these radios for the next operation: a lengthy, painful task he seemed to procrastinate about continually. Next to the radios sat a potato sack that once, James told me, was used to carry marijuana north. 
'We send them potatoes, and they send back...' With a grin, James held his hand over the final part of potatoes, so the bag now read "pot." I gave a chuckle.

'I hear that the pot from Mexico isn't as good as the legal stuff here,' I ventured.

'It's always been shit. My friend was growing it for years in California and never told me. He went out of business when it was legalized.'

'Did he not tell you because of this?' I asked, indicating Border Watch.

'I told him I don't care about it. I care about the dirtbags carrying it.'

And with that, we returned again to the violence of the Cartel.

'These fuckers chop people up while they're alive. Burn them in acid, for fun. Here, let me show you this.' And we turned and sat at a computer by the door. After moving a few radios from the keyboard, James brought up a video, 'this was taken about 20 miles from here last month.'

The motion-activated camera, left by a gate in the border fence, showed a horse on the edge of the frame. A stocky man in military fatigues was in the process of getting off it, an assault rifle strapped to his back. In time, others appeared in the frame. One in a chest rig carried a similarly large assault rifle and wandered around. The men began chatting, relaxing. Finally, a man in civilian clothes wearing a baseball cap sat atop the fence. 'This guy is the high-value guy. They are all protecting him. He's a Muslim.' James stated, looking at me sideways. 'You don't see this kind of protection for just anyone, but they don't cross now.'

A younger man in a camouflage top and jeans jumped the gate and disappeared from the camera's view. He returned shortly with a can. 'There is a [humanitarian] drop just back behind the camera. He's brought back beans for the VIP.' With a sarcastic laugh, James added, 'looking for a better life.'

The primary narrative within Border Watch presented the border as a region controlled by the Cartel, who funneled drugs and violence north to impact the lives of those in US communities. The narrative contained implicit, and sometimes explicit references to Evil and Good. There is some gradation between these extremes, and some volunteers wrestled with the complexities of the border's reality. But the narratives clearly highlighted a perceived threat to innocent US citizens from the 
Evil Cartel members. These narratives, stark and simplistic in their polemic concept, reflected broader discourses surrounding national boundaries.

Reece Jones $(2011,2012$ ) has linked the creation of the Homeland security department to a change in discourses of fear. Previous discourses, Jones argued, maintained a fear of the Other as defined against the self, but this Other was out there and never came home. Increasing concerns over migration in the 1990s and the events of September 11, 2001, 'demonstrated that "the other" was increasingly over here' (Jones 2011, 215). Borders, for Jones, are the sites at which a distinction is made between an Us and Them. In response to the 2001 attacks which felled the World Trade Centers in New York, the US government formed the Department of Homeland Security in 2002. The Department's growing emphasis on the border with Mexico from 2005 reflected a trend of separation, securitization (Heyman 2008), and in particular, the conception of a dangerous southern Other in which immigration is routinely conflated with security concerns. The concept of a porous and unsecured border heightened fears that any external threat may freely enter the US. The video James showed me indicated the multi-faceted threat an unsecured border represented to the volunteers of Border Watch. The correlation between Islamic terrorism and the Cartel is common in Border Watch and in media they consume (For some examples see: Raso 2017, Judicial Watch 2016a, b). The volunteers understood the border region to be controlled by the Cartel and that Islamic terrorism could not enter without the aid or blessing of the Cartel. As a result, though some conversations formed around Islamic terrorism, the conversations on the border centered on the brutality of the Cartel. The reports of the Maria Salvatrucha (MS-13) gang's crimes within the US and videos circulating on social media showing cartel murders and torture, presented a narrative to the volunteers that described the threat as having arrived, or in danger of imminent arrival.

The narratives of violence and danger were belied by the relative weight given to violence in particular conceptions of Mexico, and the kernel of truth found within them. There is no question that violence exists within Mexico, and when considering the US perception of Mexican Cartel violence, the changing quality is key:

'A significant proportion of homicides have been very high profile and spectacular in nature, with decapitated heads and other body parts rolled into bars or strewn about public places, bodies hanging from bridges, public assassinations of government officials, running gun battles in the public square, online posting of videotaped murders, and messages carved into flesh' (Shirk and Wallman 2015, 1354).

Howard Campbell has noted that the ritualistic killings that were frequent in Mexico during the height of troubles were: 
'especially powerful and effective because generally few people really know who committed them or exactly why; rumors spread, fears mount. The overall effect is to heighten the dominant image of the regional cartels' (Campbell 2010, 27).

It is 'the spectacular and grisly nature of gangland murders' that potentially had a more significant impact than the sheer number of homicides in sustaining the fear that 'characterizes Mexico's ongoing "public insecurity crisis"” (Shirk 2011, 1351, Bailey and Chabat 2002). In the streets of El Barrio, Philippe Bourgois highlighted a perception of violence pervaded everyday life in disproportion to the objective danger people face. He argues that because violence is traumatic and highly visible, incidents occurring during his stay contributed 'to a sense of an omnipresent threatening reality that extended far beyond the statistical possibility of becoming a victim' (Bourgois 2003, 34).

The facts of the violence, as uncomplicated as their rendition among the volunteers may have been, provided a basis of truth for their narratives. The visible and emotionally impactful violent acts defined the narrative of Mexico and the danger an unsecured border presented. On the border, one conversation led to a volunteer decrying:

'the cartels do these things to make people fear them. It does the opposite for me. It makes me angry.' He looked at me, smiled, and exclaimed, 'embrace the hate!'

The video of the "VIP" "Muslim" highlighted two aspects of the border as perceived by the volunteers of Border Watch; the internationality of the threat, and the dishonesty of the 'mainstream media' (when used by the volunteers this refers only to left-leaning news outlets) that presented an alternate narrative. For one volunteer, the mainstream media was considered to be 'full of shit... A bunch of liars and they promote false, false news all the time.' Some in Border Watch believed the videos released by the Cartel should make their way to the media outlets:

'We need more of these videos of people getting their legs chopped off and skin torn off to reach the media. That way people will understand this is what happens when you let them [Cartel] in.'

The volunteers in Border Watch had heard stories of Cartel violence. The stories told by the volunteers and the news outlets they frequented presented a narrative of violence that had spread across the unsecured border. The narrative persisted because continual anecdotal reports appeared to support it. The visible violence created a hierarchical emotional wall between potential US victims and the real victims in Central and South America. The narrative, in this sense, hid the suffering of many behind the moral obligation of protecting an Us. But what gave this 
narrative power is not fear, but its ability to make sense of the volunteers' experiences on and off the border.

\section{What Narrative Is}

Narrative is the linking of events into a definable series. It is understood as a sensemaking process. Narrative can be a story with a definitive end and beginning that ties together each element (Labov 1972) or a continual process defined in the moment of creation (Georgakopoulou 2006). Narrative is a way that 'we come to know, understand, and make sense of the social world, and it is through narratives and narrativity that we constitute our social identities' (Somers 1992, 600). There exist multiple interwoven levels of narrative. Two are of specific import here; an internalized narrative that is often used to define who we are and a collective narrative built from individual stories and experiences.

In exploring narrative identity, Steph Lawler (2014) begins by explaining that it is through linking raw materials that include memories, understandings, experiences, etc. that people form a story of who they are. She provides a disclaimer that though she is arguing identities are "made up" through making stories out of a life' (Lawler 2014, 24 emphasis in original), she is not suggesting that they are fabricated but rather creatively produced. Though identities in this sense are fiction, their reality is unquestioned by the individual who narrates them. Our identity is derived from collections of our histories and simultaneously is who we are and a narrative fiction. This dualism between reality and narrative fiction is not limited to notions of identity but also to the external world individuals reside in.

How we interpret experience is influenced by a variety of external factors and external narratives (Fivush and Haden 2003). Beyond the individual narrative is a collective ideology or collective narrative that is created through individual and collective stories (Arendt 2013). Individual stories use the collective component to articulate individual experiences, and it is through these collective narratives that individuals are able to make sense of their worlds and experiences (Jackson 2002). By using cultural narratives, individual stories become an empowering act, one that allows one to have a claim, and say in the circumstances they experience. Michael Jackson writes that in 'recounting one's own story, one salvages and reaffirms, in the face of dispersal, defeat, and death, the social bonds that bind one to a community of kindred souls' (Jackson 2002, 132-133). Narratives are situated in collective memories, stereotypes, and ideologies that act to normalize their content over a period of time so that it becomes 'self-evident, benign, uncontestable and non-controversial' (Baker 2006, 11). Because collective narratives offer a means of understanding experiences, they become a powerful element in interpreting these individual experiences and events.

In short, collective narratives offer a framework for individuals to make sense of events and experiences. Simultaneously, collective narratives are altered as the individual confirms, contests, and/or adds to the collective narrative. Lois Presser, 
writing for a narrative criminology, points out that 'while taking note of how narratives shape the world, we must also, as a matter of course, recognize that the world shapes narratives - that the influence is reciprocal' (Presser 2016, 143).

The conception of the border and the danger posed by Cartels is the narrative through which the volunteers of Border Watch make sense of their experiences and define themselves. The volunteers' narrative of the border creates a dichotomy of Good and Evil that is separated by the international border. Within this framework, the identity of the volunteers is defined by their self-ascribed positionality in standing against evil. The narratives of their lives and their narrative identity are built from their experiences and '[a]lthough this narrative activity is more of an individual accomplishment, it is only possible against the social matrix of known or imagined possible life narratives' (Bamberg 2004, 367). It is this narrative, rather than one of a humanitarian crisis, that enables the volunteers to make sense of their experiences away from the border where they dealt with the effects of drugs and violence. In this way, the volunteers' identity is intricately tied to a narrative replete with moral undertones made real through their experiences.

\section{Experience}

There are two main narratives that currently describe the United States - Mexico border. One emphasizes the suffering migrants face in their attempts to cross. The second conceptualizes the border as porous and unsecured through which 'bad hombres' cross freely. Presented as a dichotomy, the emphasis of each narrative situated them within a truth-false dichotomy. Despite the vast majority of the volunteers having no experience of the border outside of Border Watch, this second narrative resonated with their reality. The volunteers discerned the narrative's truth because it provided a means for the volunteers to make sense of their lives away from the border.

Charles vehemently advocated for the removal of undocumented migrants. Originally hailing from California, Charles left California for political reasons and now resides in Colorado. Charles once worked in the film industry in California, but since his move, he worked part-time at a restaurant. Inconsistent hours and low pay limited the time he could spend with Border Watch. Like many in Border Watch, he referred to California as 'Commie-fornia' due to his perception of Californian state-level policies. In particular, California's acceptance of undocumented migrants through 'Sanctuary-cities.' A staunch supporter of the Angel Moms (women who have lost children to violence committed by undocumented migrants), Charles advocated for the families of the men and women who had fallen victim to crimes committed by 'illegal aliens.' He argued simply that undocumented migrants were not supposed to be in the United States. After two men were killed in a drink driving accident, he wrote on social media:

'These two individuals are the latest forgotten men [sic] victims of the illegal alien policies championed by the entire political 
class in a zero-sum sympathy game focused exclusively on illegal aliens.'

In a comment on a news article discussing the murder of Mollie Tibbetts (Mollie Tibbetts disappeared in Fuly 2018; the perpetrator did not have a visa to be in the US and the murder was politicised by the Trump administration for this reason), he wrote:

'Hey LIBERALS....How many more must die before you wake up? Must it be a family member of yours who dies at the hands of an illegal alien before this sinks in? Sanctuary cities are nothing more than a haven for illegal aliens. You can start by shutting that shit down.'

Charles was vocal in his support for policies that aimed to remove undocumented migrants from the United States. He considered undocumented migrants 'matter out of place' (Douglas 2002). The issue was their existence in the US. If they were in their respective homelands, Charles argued, their crimes would not have US victims.

The collective narrative that described undocumented migrants as physically and culturally dangerous resonated with Charles' experience and conception of the world. The solution for Charles was linked to the problem; to stop the crimes committed by undocumented migrants, the porous border through which they crossed must be secured. Concerns and views like this are voiced across the United States. It is the foundation of a support base that voted for Donald Trump in the Presidential election, and, if we take Charles seriously, we can understand the genesis of his reality that this narrative resonates with.

In California, many years ago, a friend of Charles' was killed by an undocumented migrant. The distinction between legal and illegal immigration was polarized for Charles as his friend was a legal migrant from Guatemala, the murderer, an undocumented migrant. A narrative of the border that emphasizes migrant suffering was unable to help Charles make sense of this experience, whereas his experience fitted neatly within a narrative that warns of the danger a porous border presents and an evil Other waiting to cross.

Charles' experience was understandably traumatic, and it was formative in his understanding of immigration. His experience is extreme, yet speaking to the volunteers in Border Watch, it became apparent that his trauma is far from unique. A surprising number of volunteers have lost family members and/or friends to narcotic overdoses. Others worked in hospitals or in law enforcement dealing with the effects of narcotics in their communities where the effects of illegal drugs are visceral. In total, roughly $90 \%$ of volunteers had some negative experience with narcotic related violence and or crime. 
Webb Keane (2016), following Hoffman (2000) and Haidt (2001, 2000), has argued that the moral principles espoused by community members can only shape a child's ethical life when they are connected to emotion. In this sense, the principles provide the objects for consideration, and the emotions supply the motives and commitments for actions.

'If this interpretation is right, then that looping effect is evidence of an ethical affordance, in which a social project of establishing moral reason takes advantage of the emotional propensities that are already in place' (Keane 2016, 59).

Similarly, Jason Throop (Throop, 68-9), following Clifford Geertz's (1973) investigation into moral moods and feelings, argues for the central importance of moods within morality. Accepting a period of moral reflection, Throop argues these moments are less a dissatisfaction with one's situation that provokes certain moods, but:

'the "totalistic" situation characterizing an individual's (and perhaps also his or her community's) existence as such. This is not the stuff of particularized, identifiable, and bounded moral transgressions. This is instead a zone of moral evaluation in which the foundation of one's very existence as a moral being amongst other moral beings is at stake' (Throop 2014, 69).

Moods, he states, are the 'existential medium through which our reflections take shape' (Throop 2014, 70). Though moral awareness and reflection may be constant in lived experience, significant changes in ethical affordances or drastic changes in self come not from gradual refinement but from existential emotional experience.

Moods and emotion may be central to the formation of the subject position, ethical affordances, and moral assemblages, but experience alone does not define the endpoint of such reflections. Once in a reflexive state, individuals need to make sense of these experiences, and narratives provide a compelling means to do so. In turn, experience provides subjective evidence for narratives that confirm them as objective reality. For the volunteers of Border Watch, the reality of the border is that it is unsecured and the entrance point for a dangerous Other.

The majority of Border Watch volunteers accepted the evidence that migrants suffer horribly in the deserts as they attempt to enter the US and often perish on the journey. However, knowledge of these facts did not mean the volunteers accepted or believed in the narrative that focuses on this aspect. The reverse is true for individuals' relation to the narrative of the border as dangerous and porous; accepting the facts did not necessitate believing the narrative. Charles did not believe the border is the site of threat and violence because he decided to believe the narrative. Rather, his personal, emotional and traumatic experience had an exis- 
tential impact of his self. The narrative portrayed the border in a way that enabled him to make sense of his experience. Charles' identity is the narrative of his experience. The collective narrative he used to make sense of his experience simultaneously provided a narrative of his self-identity. One in which a dangerous Other threatens the US. His identity as a US citizen, in conjunction with a concept of what it means to be a citizen, created a moral obligation for action.

I have argued that the narrative of the border prevalent among the volunteers of Border Watch held value because it was visceral, produced an emotional response, and provided the volunteers a means to make sense of their experiences away from the border. But this alone is not enough to motivate hundreds of people from across the country to spend their time and money patrolling the nation's border. The narrative presents the border as the site of contestation and the location of the fight against dangerous Others. One volunteer summed up this sentiment neatly when he declared stopping drugs at the border may mean he had 'saved one life back home.'

In the following section, I explore how a historical conception of the citizen's relationship to the state combined with the dominant narrative within Border Watch to create a moral imperative for action. For the volunteers, joining one of the many border militias operating along the southern US border was a virtuous action that fulfilled this imperative.

\section{The Moral Imperative and the Citizen-Soldier}

In this article, I have explored the volunteer's perception of the border. In their view, the dominant narrative described the border as unsecured and the entrance point for those who would harm the nation. I have argued the volunteers accepted the narrative because it enabled them to make sense of their experiences at home, away from the border. Whether it was the Cartel or an unformed nebulous notion of terrorism, the constant threat the narrative evoked elaborated and instantiated a difference between the volunteers and the Other (Wilson 2017). The remainder of this article considers the concept of the citizen-soldier. I argue it is the implicit and often explicit duty within the citizen-soldier concept that underlined the volunteers' decision to join Border Watch. I do not have space within this article to discuss the gendered conceptions of morality further, but I would like to highlight that gender played a role in determining the obligations of different sections of the populace. In keeping with ancient Greek republicanism, the origin of the U.S. citizen was a limited notion. Several criteria for inclusion resulted in the permission of only men of European descent, which resulted in a gendered, racial, and classed based group (Kohn 2004, 60). Though citizenship concepts have changed somewhat since its inception, the gendered moral imperatives and view of sexual difference has not. Among the volunteers, the obligations of the citizen-soldier are reserved for the men who protect women, children, and men who cannot or choose not to defend themselves. A negative evaluation meets the latter, but women who chose to join border watch in an active role were seen to go 'above 
and beyond' their moral imperative. I argue it is this duty, as an external moral imperative, that underlined the volunteers' decision to join Border Watch.

I sat with Pouch, the owner of an Arizonan security company, by the kitchen tent and chatted quietly. The teams had just returned from another uneventful overnight mission. Mick, a former policeman, and Alex, a young man from San Francisco, joined us at the kitchen after squaring themselves away and changing out of their sweat-soaked camouflage. At the kitchen, the conversation turned to joining Border Watch.

For years, Alex 'had wanted to go, but I didn't actually get off my ass. This is where I can finally get off my ass and actually do something.'

'That's the biggest thing too, is getting people to actually, they're all outraged...' Pouch added

'well,' Mick said with knowing authority cutting off Pouch, 'a lot of them are keyboard commandos. A lot of guys can talk shit on a computer.'

'Yeah,' Pouch agreed, now talking over Mick, 'but get off their arse and actually do something.'

Undeterred, Mick continued, 'but get your arse up and weapon up and let's go friggin do something "ahh well, you know I gotta work on Monday," he finished for his imaginary opponent.

'I can't imagine half the people I know who have the same belief system as I do, and, and say the same things that I do actually even getting of their arse and coming to something like this,' Pouch concluded.

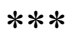

Pouch and Mick valorized their involvement through the dismissal of others who rejected the imperative to act. In particular, their friends who shared their views but did nothing. Those who 'have the same belief system as I do, and, and say the same things that I do,' are subject to the same moral imperative to act as Pouch. But their failure to act differentiated them from Pouch simultaneously marking their failure to act virtuously and Pouch's virtue in acting. The roots of this imperative can be traced to the founding of the US. In principle, the citizen-soldier is the understanding that each citizen is responsible for the defense of the nationstate. A popular retelling of the revolutionary war among militia and patriot movements has cemented the prominence of this ideal. The accepted history argues 'citizen-soldiers serving in state-based militias fought and won American independence against what was considered the finest standing army in the 
world' (Spitzer 2015, 21). In evoking a mythic retelling of the Revolutionary War, militia and patriot movements claim a direct lineage to those fighting for independence, and, for them, the revolutionary soldier's heroism reflects back on them (Mulloy 2004, 54-55). Through this lineage, modern militias and patriots claim to uphold the values of the founding fathers and, importantly, the values of the citizen-soldier. This particular retelling of the war emphasizes the individual's courage, sacrifice, and defiance, and links this to the concept of freedom.

The citizen-soldier was first to define the Civil Body Politick of Jamestown in 1620 and, subsequently, the early civic republicanism of the US (Dethloff and Shenk 2010). The value of the citizen-soldier ideal has continued despite an emphasis in the latter half of the $20^{\text {th }}$ century toward the notion of democracy (Malcolm 1996). Implicit in the duties of the republican citizen is that to enjoy the fruits of citizenship, they must share the responsibility to protect the state or nation-state from its enemies, both foreign and domestic (Snyder 2003, 187). Embedded moral connotations are paramount in the citizen-soldier ideal. Performing the duties of civic responsibility is to demonstrate the moral fortitude required of the socio-political order (Malcolm 1996, 141). Implicit in this notion is the willingness to sacrifice for one's country. Marvin and Ingle $(1999,1996)$ have argued that war is a ritual in which sacrifice builds unity. However, it is not the sacrifice of the enemy but the sacrifice of 'our' own that holds the most power so that national identity is constructed 'from the flesh and blood of group members' (Marvin and Ingle 1996, 772). If the willingness to sacrifice oneself is the ultimate form of societal inclusion, they argue, it must also be the sign of the patriot, 'the proven and true member the nation-group' (Marvin and Ingle 1996, 772-773).

The volunteers often portrayed involvement in Border Watch as a sacrifice and noted the potential sacrifices they made need to make. A freelance woodworker residing in Nevada, Todd was one of the few volunteers in Border Watch who wanted every border in the country shut down, and every undocumented migrant in the country removed. Discussing a South American born volunteer in an interview, Todd explained how he admires him because:

'He came from a long way away, and he doesn't have to. And for that matter, I didn't have to either, but we're both sacrificing our normal everyday life to be here to help out for the future of this nation.'

Later in the interview, Todd added:

'There's always an inherent sacrifice, but I'm willing to make that sacrifice, and I'm willing to make that sacrifice for my country and for the future generations and for the generations that are here right now.' 


\section{John R Parsons - Border Militias}

This was the first time Todd had spoken to me about sacrifice. This interview was far from being an interpersonal engagement between the two of us. Instead, I conducted the interview as part of a documentary that was being made about the group. I was asked to sit in as the interviewer on this occasion. Todd sat in front of three cameras, lights, and an audience of professionals and volunteers, and his answers had a defensive quality. To describe the sacrifice the foreign-born volunteer and he made to volunteer with Border Watch, Todd directly referenced the ideal of the citizen-soldier who defends, and if need be, dies for his country.

Todd and Pouch's description of their involvement in Border Watch works to form a narration of the self. Despite nuanced disagreements between scholars, a general consensus from the 'narrative turn' identifies the self as a narrative construction (Rosenwald and Ochberg 1992, Nelson and Lindemann 2001, Smith and Sparkes 2008). The narrative self must, however, be built from cultural histories that allow them to make sense:

'In the same way I cannot make sense if I use a word that I myself have made up, my actions will not make sense if they do not borrow from a cultural background. Thus, when I perform, I am carrying a history of relationships, manifesting them, expressing them' (Gergen 1999, 133).

Narrative constructions of the self are a performance, defined and altered for specific audiences and built from specific cultural histories. Narrative justifications, and the constructions of the self they form, follow the same process. Todd and Pouch demonstrated this by narrating their self through cultural histories that formulated the dominant moral imperative they adhered to.

Their words offer an insight into how they conceived their involvement within Border Watch. However, their words were delivered to an audience in what I suggest is a form of ethical performance. By this, I mean to say Todd and Pouch justified their involvement in relation to the moral imperatives of what they perceived to be the dominant moral assemblage in this instance - the notion of sacrifice and action for the nation. Their talk of sacrifice and friends who fail to act reinforces their fulfillment of the moral imperative to act in defending the security of the nation-state. Their self-identity is narrated through the citizen-soldier ideal read through a dominant narrative of the border as unsecured. The border represents the line between the dangerous Other and innocent US citizens. The narrative defined the volunteers' reality because it provided a means to understand their experience and standing against this Other reified the volunteers' sense of self as the moral citizen-soldier.

\section{Morality and Security}

In this article, I have avoided discussing the broader political methods to justify current policies of US State security, but we know the results. We have all seen the 
images of children in tears, separated from their families on the US-Mexico border. Border Watch is a microcosm of moral justification for war, nationalism, xenophobia, and so on. Border Watch is a unique, physical expression and response to broader narratives of the border, the same narratives that contributed to the separation of children from their families. As such, Border Watch provides us a window into what certain moral assemblages may provide and what they hide from us (Fassin 2012).

In the militias operating along the US-Mexico border, the lived experience of morality and security unfold. It is here that a moral imperative of the citizen-soldier ideal is operationalized in providing the incentive to act in defense of the nation and in the moral evaluation of the self. In its nature, the term narrative contains connotations of fiction. A narrative is a device we use to construct our lives, make sense of our lives, and to convince others. Narrative lives beyond us. It is a process of storytelling that encompasses many devices, but we know the veracity of them is not always guaranteed. The narratives of the border that circulate in the mainstream media, independent outlets, and on social media platforms are in and of themselves narratives. But for those with whom they resonate, the narrative describes reality. In this article, I argued that an unsecured border, viewed through the lens of the citizen-soldier, presented the volunteers of Border Watch a moral imperative to act. The dichotomous world of Good and Evil, Us and Them, separated by an international border, created a moral assemblage in Border Watch where the volunteers' subject-position (Faubion 2011) was solidified. In standing against the immoral Other, the volunteers confirmed their identity as moral citizens. However, it also blinded the volunteers to the experiences of migrants transgressing the same environment. It did so because the moral certainty of the volunteers' "Rightness" in their actions was never questioned. I suggest, the narrative of the border has blinded, or at least shielded, the supporters of the Trump administration and its firm immigration policies to the harsh realities migrants, refugees, and asylum seekers face. But justification is mainly absent because the moral "Rightness" of their actions is confirmed through a narrative of danger.

This short introduction to the activities of Border Watch and the world of the volunteers has provided a snippet of how morality is operationalized in the legitimization of actions and how morality is intrinsically linked to security in the lived experiences of Border Watch volunteers.

\section{Author Bio}

John Parsons is a graduate student at the University of Queensland in anthropology. His doctoral research concentrates on the interplay between morality, narrative, and violence on the US - Mexico border. 
Fohn R Parsons - Border Militias

\section{Acknowledgments}

I thank Josiah Heyman, Howard Campbell, and Silvia Torezani and the Center for Inter-American and Border Studies at the University of Texas at El Paso for their support, advice, and critique during the fieldwork portion of this project. Thanks also to Gerhard Hoffstaedter, Lee Wilson, Juan Zhang, and Mabel Sanchez for their enduring critique, conversations, and support. This research has been supported by an Australian Government Research Training Program (RTP) Scholarship, with additional funding provided by the School of Social Science at the University of Queensland.

\section{References}

Arendt, Hannah. 2013. The human condition. Chicago: University of Chicago Press.

Bailey, John, and Jorge Chabat. 2002. Transnational crime and public security: challenges to Mexico and the United States. San Diego: Center for US-Mexican Studies/ University of California.

Baker, Mona. 2006. Translation and conflict: A narrative account. London: Routledge. doi: https://doi.org/10.4324/9780203099919

Bamberg, Michael. 2004. "Talk, Small Stories, and Adolescent Identities." Human Development 47 (6):366-369. doi: https://doi.org/10.1159/000081039

Bourgois, Philippe I. 2003. In search of respect: selling crack in El Barrio, Structural analysis in the social sciences. Cambridge, New York: Cambridge University Press. doi: https://doi.org/10.1017/CBO9780511808562

Campbell, Howard. 2010. Drug war zone: Frontline dispatches from the streets of El Paso and Juárez. Austin: University of Texas Press.

Carrigan, William, and Clive Webb. 2003. "The Lynching of Persons of Mexican Origin or Descent in the United States, 1848 to 1928." Journal of Social History 37 (2):411-438. doi: https://doi.org/10.1353/jsh.2003.0169

Chavez, Leo R. 2008. "Spectacle in the desert: The Minuteman Project on the US-Mexico border." In Global Vigilantes: perspectives on justice and violence, edited by David Pratten and Atreyee Sen, 25-46. Hurst Publishers.

Dethloff, Henry C, and Gerald E Shenk. 2010. Citizen and Soldier: A Sourcebook on Military Service and National Defense from Colonial America to the Present. New York: Routledge. doi: https://doi.org/10.4324/9780203846483

Doty, Roxanne Lynn. 2009. The law into their own hands: Immigration and the politics of exceptionalism. Tucson: University of Arizona Press. 
John R Parsons - Border Militias

Douglas, Mary. 2002. Purity and Danger. New York: Routledge. doi: https:// doi.org/10.4324/9780203361832

Drury, Bob. 1990. Human Prey: FOX.

Fassin, Didier. 2012. "Introduction: Toward a Critical Moral Anthropology." In $A$ companion to moral anthropology, edited by Didier Fassin, 1-18. West Sussex: John Wiley \& Sons. doi: https://doi.org/10.1002/9781118290620.ch

Faubion, James D. 2011. An Anthropology of Ethics, New Departures in Anthropology. Cambridge, New York: Cambridge University Press.

Fivush, Robyn, and Catherine A Haden. 2003. Autobiographical memory and the construction of a narrative self: Developmental and cultural perspectives: Psychology Press. doi: https://doi.org/10.4324/9781410607478

Geertz, Clifford. 1973. Religion as a cultural system: The Interpretation of Cultures. New York: Basic Books.

Georgakopoulou, Alexandra. 2006. "Thinking big with small stories in narrative and identity analysis." Narrative inquiry 16 (1):122-130. doi: https:// doi.org/10.1075/ni.16.1.16geo

Gergen, Kenneth J. 1999. An invitation to social construction. London: Sage.

Hage, Ghassan. 2003. "On Worrying: the lost art of the well-administered national cuddle." Borderlands 2 (1):2.

Haidt, Jonathan. 2001. "The Emotional Dog and Its Rational Tail: A Social Intuitionist Approach to Moral Judgment." Psychological Review 108 (4):814-834. doi: https://doi.org/10.1037/0033-295X.108.4.814

Haidt, Jonathan, Fredrik Bjorklund, and Scott Murphy. 2000. "Moral dumbfounding: When intuition finds no reason." Unpublished manuscript, University of Virginia.

Heyman, Josiah McC. 2008. "Constructing a virtual wall: Race and citizenship in US-Mexico border policing." Fournal of the Southwest 50 (3):305-333. doi: https://doi.org/10.1353/jsw.2008.0010

Hoffman, Martin L. 2000. Empathy and moral development implications for caring and justice. Cambridge: Cambridge University Press. doi: https://doi.org/ $\underline{10.1017 / \mathrm{CBO} 9780511805851}$

Jackson, Michael. 2002. The politics of storytelling: violence, transgression, and intersubjectivity. Copenhagen: Museum Tusculanum Press. 
Jones, Reece. 2011. "Border security, 9/11 and the enclosure of civilisation." The Geographical fournal 177 (3):213-217. doi: https://doi.org/10.1111/ j.1475-4959.2011.00416.x

Jones, Reece. 2012. Border walls: Security and the war on terror in the United States, India, and Israel. London: Zed Books Ltd.

Judicial Watch. 2016a. "Cartels, Corruption \& Terrorism - An Investigation on the Mexican Border." Judicial Watch, June 05. https://www.judicialwatch.org/blog/2016/06/cartels-corruption-terrorism-an-investigation/

Judicial Watch. 2016b. "ISIS Terrorist Tells Feds He Has Jihadist Brothers in Mexico Confirming JW Reports." Fudicial Watch Blog: Corruption Chronicles, August 11. https://www.judicialwatch.org/blog/2016/08/isis-terroristtells-feds-jihadist-brothers-mexico-confirming-jw-reports/

Keane, Webb. 2016. Ethical life: its natural and social histories. Princeton, NJ: Princeton University Press. doi: https://doi.org/10.1515/9781400873593

Kohn, Abigail A. 2004. Shooters: Myths and realities of America's gun cultures. New York: Oxford University Press. doi: https://doi.org/10.1093/acprof:oso/ $\underline{9780195150513.001 .0001}$

Labov, William. 1972. Language in the inner city: Studies in the Black English vernacular. Vol. 3. Philadelphia: University of Pennsylvania Press.

Lawler, Steph. 2014. Identity: sociological perspectives. Cambridge: Polity.

Malcolm, Joyce Lee. 1996. To keep and bear arms: The origins of an Anglo-American right. Cambridge, US: Harvard University Press.

Marvin, Carolyn, and David W Ingle. 1996. "Blood sacrifice and the nation: Revisiting civil religion." Fournal of the American Academy of Religion 64 (4):767-780. doi: https://doi.org/10.1093/jaarel/LXIV.4.767

Marvin, Carolyn, and David W Ingle. 1999. Blood sacrifice and the nation: Totem rituals and the American flag. Cambridge, UK: Cambridge University Press.

Mize, Ronald L., and Alicia C. S. Swords. 2011. Consuming Mexican labor from the Bracero Program to NAFTA, From the Bracero Program to NAFTA: Toronto: University of Toronto Press.

Mulloy, Darren. 2004. American extremism: History, politics and the militia movement. London: Routledge. doi: https://doi.org/10.4324/9780203352069 
Nelson, Hilde Lindemann, and Hilde Lindemann. 2001. Damaged identities, narrative repair: Cornell University Press.

Presser, Lois. 2016. "Criminology and the narrative turn." Crime, Media, Culture 12 (2):137-151. doi: https://doi.org/10.1177/1741659015626203

Raso, Dom. 2017. How ISIS Could Get A Nuke Across Our Border. In NRATV: NRATV.

Rosenwald, George C, and Richard L Ochberg. 1992. Storied lives: The cultural politics of self-understanding. New Haven, London: Yale University Press.

Shapira, Harel. 2013. Waiting for José: the Minutemen's pursuit of America. New Jerrsey: Princeton University Press. doi: https://doi.org/10.1515/9781400846764

Shirk, David A. 2011. The drug war in Mexico: confronting a shared threat. Council on Foreign Relations: center for preventive action.

Shirk, David, and Joel Wallman. 2015. "Understanding Mexico's Drug Violence." The Journal of Conflict Resolution 59 (8):1348. doi: https://doi.org/ $\underline{10.1177 / 0022002715587049}$

Smith, Brett, and Andrew C Sparkes. 2008. "Contrasting perspectives on narrating selves and identities: An invitation to dialogue." Qualitative research 8 (1):5-35. doi: https://doi.org/10.1177/1468794107085221

Snyder, R Claire. 2003. "The citizen-soldier tradition and gender integration of the US military." Armed Forces E Society 29 (2):185-204. doi: https:// doi.org/10.1177/0095327X0302900203

Somers, Margaret R. 1992. "Narrativity, narrative identity, and social action: Rethinking English working-class formation.” Social Science History 16 (04):591630. doi: https://doi.org/10.1017/S0145553200016679

Spitzer, Robert J. 2015. Politics of gun control. New York: Routledge. doi: https:// doi.org/10.4324/9781315636306

Throop, G. Jason. 2014. "Moral Moods." Ethos 42 (1):65-83. doi: https://doi.org/ $\underline{10.1111 / \text { etho. } 12039}$

Tórrez, Robert J. 2008. Myth of the hanging tree: Stories of crime and punishment in territorial New Mexico. Albuquerque: University of New Mexico Press.

Wilson, Lee. 2017. "How critical can critical be? Contesting security in Indonesia." Critical Studies on Security 5 (3):302-316. doi: https://doi.org/ $\underline{10.1080 / 21624887.2018 .1424985}$ 
Zigon, Jarrett. 2009. "Morality and Personal Experience: The Moral Conceptions of a Muscovite Man." Ethos 37 (1):78-101. doi: https://doi.org/10.1111/ j.1548-1352.2009.01032.x

Zigon, Jarrett. 2010. "Moral and ethical assemblages." Anthropological Theory 10 (12):3-15. doi: https://doi.org/10.1177/1463499610370520 